\title{
EVIDENCE OF LATITUDINAL SEXUAL SEGREGATION AMONG MIGRATORY BIRDS WINTERING IN MEXICO
}

\author{
Oliver Komar, ${ }^{1,4}$ B. J. O’Shea, ${ }^{2,5}$ A. Townsend Peterson, ${ }^{1}$ \\ and Adolfo G. Navarro-SigüEnZA ${ }^{3}$
}

${ }^{1}$ Natural History Museum and Biodiversity Research Center, University of Kansas, Lawrence, Kansas 66045, USA; ${ }^{2}$ Department of Zoology, Division of Birds, The Field Museum, 1400 South Lake Shore Drive, Chicago, Illinois 60605, USA; and

${ }^{3}$ Museo de Zoología, Facultad de Ciencias, Universidad Nacional Autónoma de México, Apartado Postal 70-399, México DF 04510, México

\begin{abstract}
Latitudinal sexual segregation during the nonbreeding season, in which males tend to winter farther north than females, is known to occur in many temperate-zone bird species. This pattern, however, has rarely been reported in species wintering in tropical regions. We investigated latitudinal sexual segregation in 45 Nearctic-Neotropical migratory bird species that winter in Mexico, using specimen records from 35 natural-history museums. We found significant latitudinal segregation in nine species: Yellow-bellied Sapsucker (Sphyrapicus varius), Swainson's Thrush (Catharus ustulatus), Orange-crowned Warbler (Vermivora celata), Yellow Warbler (Dendroica petechia; aestiva group), Yellow-rumped Warbler (Dendroica coronata; coronata group), Black-and-white Warbler (Mniotilta varia), Ovenbird (Seiurus aurocapilla), Wilson's Warbler (Wilsonia pusilla), and Indigo Bunting (Passerina cyanea). In most cases, males predominated in the northern part of species' winter ranges and females in the south, but the trend was reversed in Indigo Buntings. Discovering the frequency of latitudinal sexual segregation in Neotropical migratory birds will influence understanding of avian ecology and migration systems. Received 28 January 2003, accepted 1 March 2005.
\end{abstract}

Key words: differential migration, Nearctic-Neotropical migration, Neotropics, sexual segregation.

Evidencia de la Segregación Latitudinal Sexual en Aves Migratorias durante el Invierno en México

Resumen.-Se sabe que la segregación latitudinal de sexos durante la temporada no reproductiva ocurre en muchas especies de aves de la región templada, en las cuales los machos predominan en las zonas norteñas de las distribuciones de invierno. No obstante, este patrón raramente ha sido reportado en especies que invernan en las regiones tropicales. Analizamos 45 especies que invernan en México con base en especímenes alojados en 35 museos de historia natural, para investigar cuáles especies podrían mostrar segregación latitudinal entre sexos. Encontramos patrones significativos de segregación en 9 especies: Sphyrapicus varius, Catharus ustulatus, Vermivora celata, Dendroica petechia (grupo aestiva), Dendroica coronata (grupo coronata), Mniotilta varia, Seiurus aurocapilla, Wilsonia pusilla y Passerina cyanea. En general, los machos predominaron al norte de su distribución invernal, mientras que las hembras fueron relativamente más

\footnotetext{
${ }^{4}$ Present address: Conservation Science Program, SalvaNATURA, 33 Ave. Sur No. 640, Colonia Flor Blanca, San Salvador, El Salvador. E-mail: okomar@salvanatura.org

${ }^{5}$ Present address: Department of Biological Sciences, and Museum of Natural Science, 119 Foster Hall, Louisiana State University, Baton Rouge, Louisiana 70803, USA.
} 
comunes al sur, pero el patrón fue el inverso para $P$. cyanea. El descubrimiento de la extensión de la segregación sexual latitudinal en aves migratorias neotropicales influenciará el entendimiento de la ecología de las aves y los sistemas migratorios.

THE TENDENCY FOR male and female birds to segregate during the nonbreeding season was first noted in partial migrants, in which males tend to occupy breeding ranges year-round but females migrate to areas with warmer temperatures (Laskey 1935, Nice 1937, Lack 1954). Gradually, researchers in Holarctic regions noted that many short- and medium-distance migrants also exhibit patterns of latitudinal (or geographic) sexual segregation on the wintering grounds, with males generally wintering farther north than females (Howell 1953, King et al. 1965, Ketterson and Nolan 1983). Now, distinct winter distribution patterns between sexes (and frequently age classes also) have been documented for more than 100 species (Cristol et al. 1999).

In spite of occasional reports of winter latitudinal sexual segregation in long-distance Nearctic-Neotropical migrants (Howell 1953, Johnston 1970, Pearson 1980, Russell 1981), segregation has been largely overlooked in this group and was assumed to be rare (Morton 1990). Indeed, only in the past decade was it reported from Neotropical wintering grounds of two parulid warblers (Vidal et al. 1994, Sherry and Holmes 1997). Cristol et al. (1999), reviewing differential migration, predicted that latitudinal segregation occurs more widely than has been reported. Discovering the extent of latitudinal segregation in Neotropical migratory birds on their wintering grounds is important for understanding migratory behavior and the ecology of migratory species in tropical bird communities. The existence of such segregation has far-reaching consequences: segregation could lead to different annual survival rates between sexes or evolution of different habitat preferences, either of which could influence conservation strategies for threatened species. Also, such patterns imply that selective forces may differ between males and females, because of differences in habitat, geography, and local components of ecosystems.

In most latitudinally segregated species, males winter farther north than females (Cristol et al. 1999), so explanations have focused on explaining why males winter farther north. One popular hypothesis is that the territorial sex (males) winters farther north to be able to return earlier to breeding grounds to claim territories (King et al. 1965; Ketterson and Nolan 1976, 1983). In temperate areas, another explanation for males wintering farther north is that the larger sex (males) can physiologically withstand colder temperatures (Ketterson and Nolan 1976). Alternatively, geographic segregation may result from intersexual competition: Lack (1954) suggested that the dominant sex may exclude the other from some areas. The hypothesis that sexes have evolved different foraging niches in response to intersexual competition (Selander 1966, Lynch et al. 1985, Morton 1990) can be extended to include geographic wintering areas, if those areas are interpreted as one element of the foraging niche.

Here, we ask the question: how common is latitudinal sexual segregation among a diverse set of medium to long-distance Nearctic-Neotropical migratory species on their wintering grounds? The group of species studied includes 3 hummingbirds, 1 woodpecker, 6 tyrannid flycatchers, 2 vireos, 1 kinglet, 2 thrushes, 1 catbird, 18 parulid warblers, 2 tanagers, 3 emberizid sparrows, 4 cardinalid buntings, and 2 icterid orioles (all common and scientific names given in Table 1).

\section{Methods}

We extracted records of migratory birds from a comprehensive database of bird specimens from Mexico (Atlas of Mexican Bird Distributions project; Peterson et al. 1998, Navarro S. et al. 2002, 2003; institutions listed in Appendix). We used only records for which precise locality data were available, and for which collecting date was within December-February, to minimize inclusion of transient individuals (Ketterson and Nolan 1976, Remsen 2001). We also excluded species that do not form winter home ranges and, in effect, are transients throughout the winter period (e.g. Cedar Waxwing [Bombycilla cedrorum]), and species that have permanent resident breeding populations in Mexico (e.g. Lesser Nighthawk [Chordeiles acutipennis], Broad-tailed Hummingbird [Selasphorus 


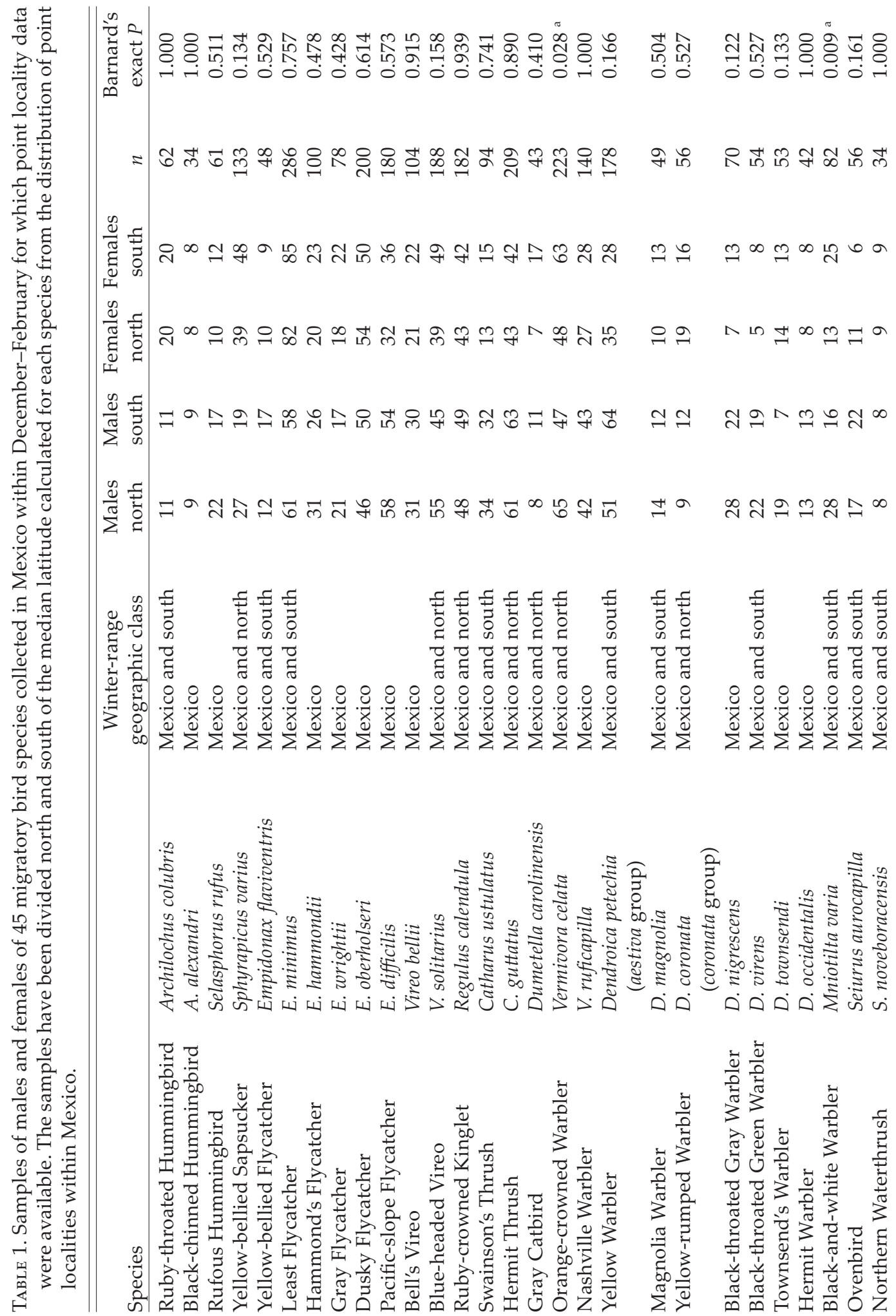




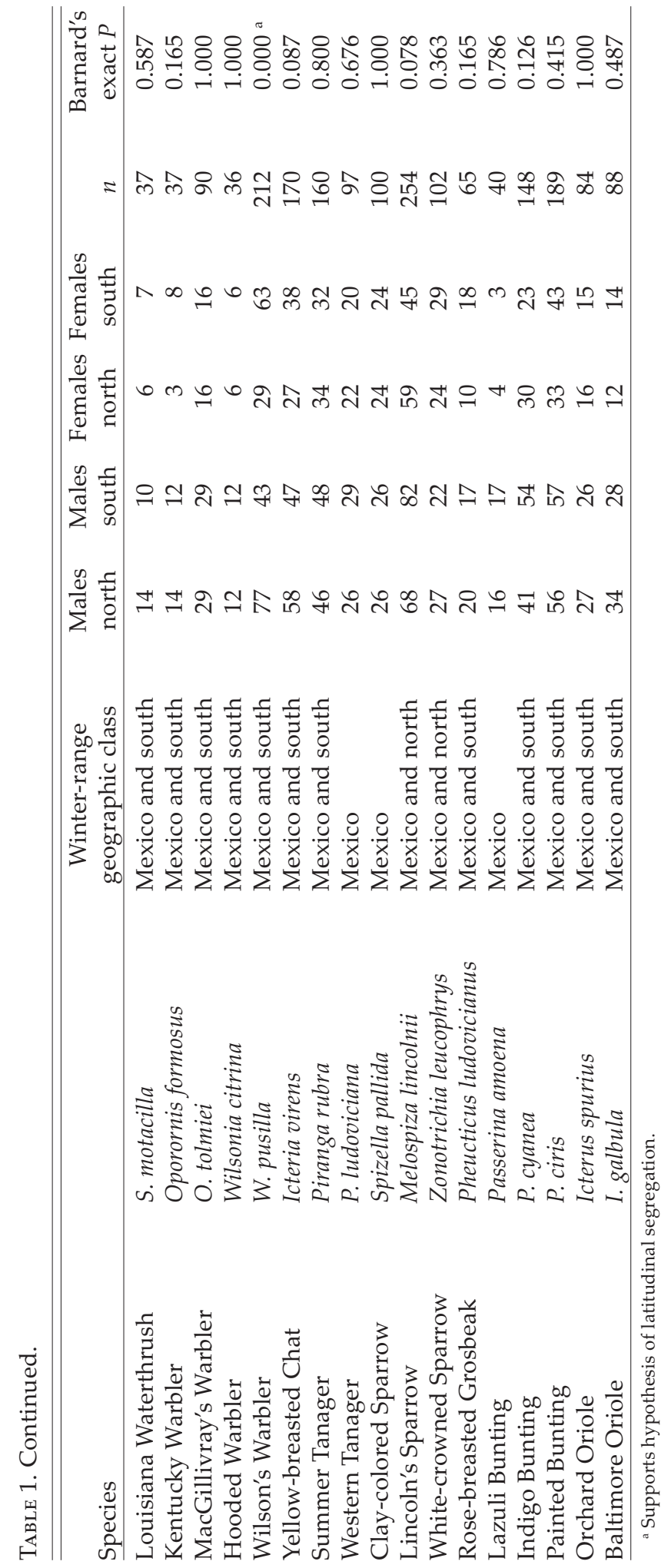


platycercus]), to ensure that all individuals in our analyses were medium- or long-distance migrants. We excluded specimens from one collector (M. del Toro Avilés) known for doubtful date and locality information (Binford 1989) and excluded all species for which $<30$ records were available.

For the 45 remaining species, we sorted records by latitude and tested for differences in numbers of each sex north and south of the median latitude in the Mexican data set. Individuals collected at exactly the median latitude were excluded, because they could not be assigned to either northern or southern groups. We used contingency-table analysis to compare frequencies of each sex, north versus south, with $P$ values determined using Barnard's test ( $\alpha=0.05$ ), which is an exact unconditional test of equality of two binomial proportions (STATXACT, Cytel Software, Cambridge, Massachusetts) and is appropriate for model I contingency tables (Sokal and Rohlf 1995). We did not correct alphas for multiple comparisons because (1) that would assume the universal null hypothesis (no geographic differences across sex classes in any and all species) to be relevant, obviating the biological significance of the tests and the a priori expectation that meaningful patterns might exist (Perneger 1998); and (2) it would increase Type II error rates.

Given that the expected pattern of sexual segregation across Mexico may be different for species that winter mostly to the north or mostly to the south, we classified each species into one of three geographic range classes: wintering (1) mainly in Mexico, (2) substantially to the north, or (3) substantially to the south of Mexico. We defined "substantial" as approximately $40 \%$ or more of the winter range, and based our classifications on published accounts and range maps of winter ranges (species accounts in Birds of North America series, and American Ornithologists' Union 1998).

For species with substantial winter ranges north or south of Mexico, we determined the probability $(P)$ that the overall sex ratio in the Mexican sample was equal to unity, based on cumulative expected frequencies for the rarer sex generated from the binomial distribution. We doubled the expected frequencies to obtain $P$, because either sex could have been rarer than the other (we did not know a priori the direction of segregation patterns); hence, the statistical test was two-tailed. Given the tendency for most cases of documented sexual segregation to be in one direction (males predominating to the north and females to the south), a one-tailed test may have been appropriate, but the two-tailed test is more conservative.

For species in the northerly or southerly groups with significantly skewed sex ratios in Mexico, we further investigated sex ratios from other parts of their wintering ranges. We queried 10 museum collection databases (Academy of Natural Sciences, Philadelphia, Pennsylvania; Delaware Museum of Natural History, Wilmington; The Field Museum, Chicago [FMNH]; Louisiana State University Museum of Natural Science, Baton Rouge [LSU]; Museo Nacional de Costa Rica, San José; Museum of Vertebrate Zoology, Berkeley, California; Peabody Museum, Yale University, New Haven, Connecticut; Universidad de Panamá Museo de Vertebrados, Ciudad de Panamá; University of Kansas Natural History Museum, Lawrence; and U.S. National Museum of Natural History, Washington, D.C.) for non-Mexican wintering records. For species wintering north of Mexico, we counted all records of males and females collected in the United States, excluding Florida, during December, January, or February. For species wintering south of Mexico, we counted all records of males and females collected in Costa Rica or Panama to determine representative sex ratios from the southern part of the winter range. For two species that winter more broadly southward, we also checked collections (FMNH, LSU) from South America (mostly Colombia and Peru) to see whether sex ratios farther south differed.

For species wintering mostly within Mexico, we were interested in the possibility of clinal variation in sex ratios, which might not be detected by the above methods. We selected the 12 species with samples of $\geq 60$ specimens for analysis, divided their locality records into latitudinal quartiles, and compared the sex ratios in the northernmost and southernmost quartiles by contingency-table analysis, using Barnard's exact tests. Data from localities that fell exactly on the limits between latitudinal quartiles were excluded.

\section{Results}

Significant $(P<0.05)$ segregation of sexes was found in 9 of 45 species. Segregation around 
TABLE 2. Samples of males and females of migratory bird species wintering mostly in Mexico, from northernmost and southernmost latitudinal quartiles for specimens collected in Mexico within December-February. The quartiles were derived independently for each species from the point localities of museum specimens collected in Mexico.

\begin{tabular}{lcccccc}
\hline Species & $\begin{array}{c}\text { Males } \\
\text { north }\end{array}$ & $\begin{array}{c}\text { Males } \\
\text { south }\end{array}$ & $\begin{array}{c}\text { Females } \\
\text { north }\end{array}$ & $\begin{array}{c}\text { Females } \\
\text { south }\end{array}$ & $n$ & $\begin{array}{c}\text { Barnard's } \\
\text { exact } P\end{array}$ \\
\hline Selasphorus rufus & 13 & 11 & 3 & 9 & 36 & 0.099 \\
Empidonax hammondii & 17 & 12 & 8 & 12 & 49 & 0.240 \\
E. wrightii & 12 & 8 & 7 & 11 & 38 & 0.256 \\
E. oberholseri & 21 & 25 & 22 & 24 & 92 & 0.872 \\
E. difficilis & 27 & 27 & 15 & 18 & 87 & 0.738 \\
Vireo bellii & 13 & 15 & 12 & 9 & 49 & 0.525 \\
Vermivora ruficapilla & 23 & 21 & 12 & 10 & 66 & 0.884 \\
Dendroica nigrescens & 12 & 12 & 4 & 5 & 33 & 0.817 \\
D. townsendi & 10 & 4 & 5 & 6 & 25 & 0.225 \\
Piranga ludoviciana & 15 & 12 & 8 & 8 & 43 & 0.756 \\
Spizella pallida & 8 & 12 & 15 & 13 & 48 & 0.528 \\
\hline
\end{tabular}

the median latitude of Mexican distributional records (Table 1) occurred in Orange-crowned Warbler, Black-and-white Warbler, and Wilson's Warbler. In all three, males were more frequent than females in the northern part of the wintering distribution. For species wintering principally in Mexico, we compared sex ratios from the northernmost quartile to the southernmost quartile; none of the sex ratios differed significantly (Table 2).

Of species wintering extensively north of Mexico, three of nine showed significantly unequal sex proportions in Mexico, but only two of nine showed sex ratios in Mexico significantly different from sex ratios in the United States (Table 3). In both Yellow-bellied Sapsucker and Yellow-rumped ("Myrtle") Warbler, females outnumbered males in Mexico, but males outnumbered females in the United States, a pattern consistent with latitudinal sexual segregation.

Among species wintering extensively south of Mexico, 14 of 22 showed sex ratios in Mexico significantly different from unity, and 3 others had nearly significant $(0.05<$ $P<0.10)$ differences (Table 4 ). In most cases,

TABle 3. Samples of males and females of northerly wintering bird species collected in Mexico and the United States (except Florida) within December-February. P-equity represents the probability that the Mexican sample was taken from a population with equal numbers of males and females. Barnard's exact $P$ is the probability that the ratios in Mexico and the United States are the same; this statistic and United States sample sizes are provided only for species with significantly skewed sex ratios in Mexico and for Dendroica coronata.

\begin{tabular}{|c|c|c|c|c|c|c|}
\hline \multirow[b]{2}{*}{ Species } & \multicolumn{3}{|c|}{ Mexico } & \multicolumn{2}{|c|}{ United States } & \multirow{2}{*}{$\begin{array}{c}\text { Barnard's } \\
\text { exact } P\end{array}$} \\
\hline & Males & Females & $P$-equity & Males & Females & \\
\hline Sphyrapicus varius & 46 & 87 & 0.0004 & 96 & 76 & $0.0002^{a}$ \\
\hline Vireo solitarius & 100 & 88 & 0.4220 & & & \\
\hline Regulus calendula & 97 & 85 & 0.4150 & & & \\
\hline Catharus guttatus & 124 & 85 & 0.0080 & 244 & 152 & 0.5890 \\
\hline Dumetella carolinensis & 19 & 24 & 0.5420 & & & \\
\hline Vermivora celata & 112 & 111 & 1.0000 & & & \\
\hline Dendroica coronata (coronata group) & 21 & 35 & 0.0810 & 130 & 87 & $0.0030^{\text {a }}$ \\
\hline Melospiza lincolnii & 150 & 104 & 0.0050 & 55 & 56 & 0.0960 \\
\hline Zonotrichia leucophrys & 49 & 53 & 0.7660 & & & \\
\hline
\end{tabular}

a Supports hypothesis of latitudinal segregation. 
TABle 4. Samples of males and females of southerly wintering bird species collected in Mexico within December-February, and in southern Central America (Costa Rica or Panama) on any date. $P$-equity represents the probability that the Mexican sample was taken from a population with equal numbers of males and females. Barnard's exact $P$ is the probability that the sex ratios in Mexico and in southern Central America are the same; this statistic and Central American sample sizes are provided generally only for species with skewed sex ratios $(P<0.05)$ in Mexico.

\begin{tabular}{|c|c|c|c|c|c|c|}
\hline \multirow[b]{2}{*}{ Species } & \multicolumn{3}{|c|}{ Mexico } & \multicolumn{2}{|c|}{$\begin{array}{c}\text { Southern } \\
\text { Central America }\end{array}$} & \multirow{2}{*}{$\begin{array}{c}\text { Barnard's } \\
\text { exact } P\end{array}$} \\
\hline & Males & Females & $P$-equity & Males & Females & \\
\hline Archilochus colubris & 22 & 40 & 0.030 & 10 & 11 & 0.420 \\
\hline Empidonax flaviventris & 29 & 19 & 0.193 & & & \\
\hline E. minimus & 119 & 167 & 0.005 & 2 & 3 & 0.965 \\
\hline Catharus ustulatus & 66 & 28 & 0.0002 & 29 & 17 & 0.415 \\
\hline Dendroica petechia (aestiva group) & 115 & 63 & 0.0002 & 91 & 87 & $0.010^{\mathrm{a}}$ \\
\hline D. magnolia & 26 & 23 & 0.775 & & & \\
\hline D. virens & 41 & 13 & 0.0002 & 58 & 38 & 0.056 \\
\hline Mniotilta varia & 44 & 38 & 0.581 & 34 & 15 & 0.077 \\
\hline Seiurus aurocapilla & 39 & 17 & 0.005 & 12 & 15 & $0.028^{a}$ \\
\hline S. noveboracensis & 16 & 18 & 0.864 & & & \\
\hline S. motacilla & 24 & 13 & 0.099 & & & \\
\hline Oporornis formosus & 26 & 11 & 0.020 & 54 & 26 & 0.797 \\
\hline O. tolmiei & 58 & 32 & 0.008 & 3 & 3 & 0.576 \\
\hline Wilsonia citrina & 24 & 12 & 0.065 & & & \\
\hline W. pusilla & 120 & 92 & 0.063 & 90 & 69 & 1.000 \\
\hline Icteria virens & 105 & 65 & 0.003 & 2 & 4 & 0.199 \\
\hline Piranga rubra & 94 & 66 & 0.032 & 120 & 86 & 0.928 \\
\hline Pheucticus ludovicianus & 37 & 28 & 0.321 & & & \\
\hline Passerina cyanea & 95 & 53 & 0.001 & 30 & 4 & $0.006^{\mathrm{a}}$ \\
\hline P. ciris & 113 & 76 & 0.009 & 10 & 6 & 0.909 \\
\hline Icterus spurius & 53 & 31 & 0.021 & 40 & 16 & 0.319 \\
\hline I. galbula & 62 & 26 & 0.0002 & 49 & 17 & 0.615 \\
\hline
\end{tabular}

a Supports hypothesis of latitudinal segregation.

males outnumbered females in Mexico, though females outnumbered males in Ruby-throated Hummingbird and Least Flycatcher. Comparing sex ratios of the same species collected in Costa Rica and Panama, only three species (Yellow Warbler, Ovenbird, and Indigo Bunting) presented significantly different ratios in Central American samples. Samples of Yellow Warbler and Ovenbird from Central America held proportionally more females than Mexican samples, and vice versa for Indigo Bunting (Table 4).

In South America, the Swainson's Thrush was represented in collections by 88 males and 75 females. Although males outnumbered females in all geographic regions examined, the proportion of females was significantly higher in South America than in the Mexican sample of that species $(P=0.011)$. The Summer Tanager, a species skewed toward males in Mexico as well as in Central America, showed similar skew toward males in South American collections (33 males, 23 females).

\section{Discussion}

Overall, we found evidence of latitudinal sexual segregation in 9 species (20\% of 45 studied) wintering in Mexico. In eight of those cases, males wintered to the north in greater proportions than females (the exception was Indigo Bunting). Our results support earlier reports of latitudinal segregation in Yellow-bellied Sapsucker (Howell 1953), Yellow-rumped Warbler (Hunt and Flaspohler 1998), and Indigo Bunting (Johnston 
1970). The other six species have not previously been reported to segregate latitudinally, but studies of segregation on Neotropical wintering grounds have been few (Cristol et al. 1999). Six parulid warblers (one-third of warbler species studied) demonstrated the pattern, which may be more prevalent in Parulidae than in other families, such as Tyrannidae. Latitudinal sexual segregation was not evident in any of the six tyrannid species studied.

Some of the cases of latitudinal sexual segregation reported here are supported by greater numbers of males in one geographic region and greater numbers of females in another. However, in Indigo Bunting and Swainson's Thrush, the evidence is limited to variation in the dimensions of the skew toward males. In those species, males are generally better represented in museum collections than females, evidently throughout the winter range. These particular results should thus be interpreted with caution. To demonstrate latitudinal segregation more conclusively, we would prefer to identify geographic areas where opposite skews would be expected, and carry out tests there. Unfortunately, key series of specimens from Central or South America necessary for such tests were sometimes simply not available, pointing to the continuing need for scientific collecting in many regions (e.g. Central American sample sizes for Hooded Warbler and Yellow-breasted Chat were 2 and 6, respectively). Skewed sex ratios in themselves may suggest latitudinal segregation, but could also reflect sampling bias or real skews in overall wintering populations.

In fact, many species showed significant sex ratio skews in the same direction (more males) across much of their winter ranges. For example, among Hermit Thrush specimens, males outnumbered females in Mexico and across the United States during winter (Table 3); other species showed similar patterns (e.g. Summer Tanager and Baltimore Oriole). This pattern may result from greater detectability of males owing to brighter plumage, from more frequent or longer-distance movements by males compared with females, from male preferences for more open habitats, or from collector preferences, among other possible factors. For sexually dimorphic species, such as Summer Tanager and Painted Bunting, collector bias may be strongly influencing sex ratios in collections: some collectors may prefer to collect flashy, colorful males, whereas others may collect just enough of either sex to ensure equal representation. Either practice would obscure natural patterns of uneven sex ratios. Additional methods, such as standardized mist-netting, may be needed to investigate the possibility of latitudinal sexual segregation in such species. Nonetheless, if existing biases are consistent across a species' range, which we assume to be true, they should not affect our ability to discern significant differences in sex ratios among geographic regions.

True patterns of geographic segregation in some species may be too complex to detect by examination of museum-specimen data alone, without new field studies designed to test hypotheses of latitudinal segregation. For example, differential distributions of age classes, well-documented in some species (Cristol et al. 1999), will require inspection of specimens for further analysis.

Some of our results may reflect more complex sex-specific distributions. For example, in the Black-and-white Warbler, a species with extensive wintering populations south of Mexico, males outnumbered females in the northern half of the Mexican winter samples, and females outnumbered males in the southern half. Unexpectedly, in southern Central America, males outnumbered females 34 to 15 (Table 4), whereas in northern Central America (El Salvador), females outnumbered males 17 to 4 (O. Komar unpubl. data). A similar pattern is evident for Wilson's Warbler (Table 4). The question remains, why would males outnumber females in northern Mexico and southern Central America, but be outnumbered by females in intervening areas? Also unexpected was the prevalence of males in the Mexican sample of Lincoln's Sparrow, given that the U.S. sample showed equity in the sex ratio (Table 3). In all those cases, it is possible that latitudinal age segregation occurs, complicating the pattern. Future research should address the question of age segregation in greater detail. Unfortunately, reliable age information for specimens is not available in most museum databases.

Several species previously reported to segregate sexes latitudinally on wintering grounds did not show such patterns in our analysis: Ruby-crowned Kinglet (Humple et 
al. 2001), Summer Tanager (Pearson 1980), and White-crowned Sparrow (King et al. 1965). Our inability to detect segregation in those species may result from several factors: (1) segregation may be evident only at extremes of the winter range, given clinal variation in sex ratios; (2) for sexually dimorphic species, samples may be biased by collectors' preferences, such that sex ratios in collections differ from true ratios in nature; or (3) for species that segregate by habitat in winter, samples may be biased by uneven collecting effort among habitats. More generally, either previous documentations were not representative of larger-scale distributional patterns, or our analyses lack statistical power.

Moreover, geographic segregation does not necessarily have to be latitudinal. In fact, we used latitude only as an initial measure to evaluate whether geographic segregation is a common pattern. Geographic segregation might sort out more frequently in other dimensions, such as Atlantic versus Pacific drainage, elevation, temperature, or habitat features that may or may not be correlated with latitude. Habitat features have been shown to differentially influence abundances of sexes at local scales in many wintering parulid warblers (Rappole and Warner 1980, Lynch et al. 1985, López Ornat and Greenberg 1990, Wunderle 1992, Parrish and Sherry 1994, Wallace et al. 1996, Murphy et al. 2001). Local habitat segregation on wintering grounds has been reported in other species as well (Nisbet and Medway 1972, Rappole 1995). All those factors suggest that local patterns of sexual segregation may not be representative across the winter range. Just as habitat use and overall density of many species in winter vary with latitude, so may sex ratios.

Although our results indicate winter latitudinal sexual segregation in several species, our data were not collected in the context of studies designed for such analysis. Although we are unsure of the real biases in the data, we believe that the data come from sufficiently diverse sources so that biases have not obscured real patterns. We hope that the present study inspires new field studies specifically designed to address questions of geographic segregation. In spite of the growing literature on sexual segregation in some long-distance migratory bird species (Cristol et al. 1999, Nebel et al. 2002, results presented herein), this pattern has not been reported for many long-distance
Nearctic-Neotropical migrants, nor has it been reported for any Palearctic or Austral migrants. We suggest that such patterns may prove widespread, once broad-scale data sets covering large portions of winter ranges become accessible. Because many winter ranges are in tropical areas, which tend to be undersampled in museum collections, expansion of museum collections of wintering migratory birds would be useful to elucidate these phenomena.

\section{Acknowledgments}

We thank M. T. Murphy, G. E. Wallace, and three anonymous reviewers for comments on the manuscript. Museums supplying access to specimens and associated data are listed in the Methods section and in the Appendix. G. Alvarado, J. Dean, G. K. Hess, N. H. Rice, M. B. Robbins, and V. H. Tejera-N. kindly helped us extract data from museum collections. A. Gordillo georeferenced specimen localities for the Atlas of Mexican Bird Distributions. O.K. acknowledges the support of a National Science Foundation Graduate Research Fellowship. The Atlas of Mexican Bird Distributions project was funded by CONABIO, CONACyT, DGAPAUNAM, British Council (Mexico), and the U.S. National Science Foundation.

\section{Literature Cited}

American Ornithologists' Union. 1998. Checklist of North American Birds, 7th ed. American Ornithologists' Union, Washington, D.C.

Binford, L. C. 1989. A distributional survey of the birds of the Mexican state of Oaxaca. Ornithological Monographs, no. 43.

Cristol, D. A., M. B. Baker, and C. Carbone. 1999. Differential migration revisited: Latitudinal segregation by age and sex class. Pages 33-88 in Current Ornithology, vol. 15 (V. Nolan, Jr., E. D. Ketterson, and C. F. Thompson, Eds.). Plenum Press, New York.

Howell, T. R. 1953. Racial and sexual differences in migration in Sphyrapicus varius. Auk 70:118-126.

Humple, D. L., N. Nur, G. R. Geupel, and M. P. Lynes. 2001. Female-biased sex ratio in a wintering population of Ruby-crowned Kinglets. Wilson Bulletin 113:419-424.

Hunt, P. D., And D. J. Flaspohler. 1998. Yellowrumped Warbler (Dendroica coronata). In 
The Birds of North America, no. 376 (A. Poole and F. Gill, Eds.). Academy of Natural Sciences, Philadelphia, and American Ornithologists' Union, Washington, D.C.

Johnston, D. W. 1970. Age and sex distribution in Indigo Buntings. Bird-Banding 41: 113-118.

Ketterson, E. D., and V. Nolan, JR. 1976. Geographic variation and its climatic correlates in the sex ratio of eastern-wintering Dark-eyed Juncos (Junco hyemalis hyemalis). Ecology 57:679-693.

Ketterson, E. D., and V. Nolan, Jr. 1983. The evolution of differential bird migration. Pages 357-402 in Current Ornithology, vol. 1 (R. F. Johnston, Ed.). Plenum Press, New York.

King, J. R., D. S. Farner, and L. R. Mewaldt. 1965. Seasonal sex and age ratios in populations of the White-crowned Sparrows of the race gambelii. Condor 67:489-504.

LACK, D. 1954. The Natural Regulation of Animal Numbers. Clarendon Press, Oxford.

LAskey, A. R. 1935. Mockingbird life history studies. Auk 52:370-381.

López Ornat, A., and R. Greenberg. 1990. Sexual segregation by habitat in migratory warblers in Quintana Roo, Mexico. Auk 107: 539-543.

Lynch, J. F., E. S. Morton, and M. E. VAn deR Voort. 1985. Habitat segregation between the sexes of wintering Hooded Warblers (Wilsonia citrina). Auk 102:714-721.

Morton, E. S. 1990. Habitat segregation by sex in the Hooded Warbler: Experiments on proximate causation and discussion of its evolution. American Naturalist 135: 319-333.

Murphy, M. T., A. Pierce, J. Shoen, K. L. Murphy, J. A. Campbell, and D. A. Hamilton. 2001. Population structure and habitat use by overwintering Neotropical migrants on a remote oceanic island. Biological Conservation 102:333-345.

Navarro S., A. G., A. T. Peterson, and A. Gordillo-Martínez. 2002. A Mexican case study on a centralised data base from world natural history museums. Data Science Journal 1:45-53.

Navarro S., A. G., A. T. Peterson, and A. Gordillo-Martínez. 2003. Museums working together: The atlas of the birds of Mexico. Pages 207-225 in Why Museums Matter:
Avian Archives in an Age of Extinction (N. Collar, C. Fisher, and C. Feare, Eds.). Bulletin of the British Ornithologists' Club, Supplement 123A.

Nebel, S., D. B. Lank, P. D. O'Hara, G. Fernández, B. Haase, F. Delgado, F. A. Estela, L. J. Evans Ogden, B. Harrington, B. E. Kus, AND OTHERs. 2002. Western Sandpipers (Calidris mauri) during the nonbreeding season: Spatial segregation on a hemispheric scale. Auk 119:922-928.

Nice, M. M. 1937. Studies in the life history of the Song Sparrow, I. Transactions of the Linnaean Society of New York, no. 4.

Nisbet, I. C. T., and L. Medway. 1972. Dispersion, population ecology and migration of Eastern Great Reed Warblers Acrocephalus orientalis wintering in Malaysia. Ibis 114:451-494.

PArrish, J. D., ANd T. W. Sherry. 1994. Sexual habitat segregation by American Redstarts wintering in Jamaica: Importance of resource seasonality. Auk 111:38-49.

Pearson, D. L. 1980. Bird migration in Amazonian Ecuador, Peru, and Bolivia. Pages 273-283 in Migrant Birds in the Neotropics: Ecology, Behavior, Distribution, and Conservation (A. Keast and E. S. Morton, Eds.). Smithsonian Institution Press, Washington, D.C.

Perneger, T. V. 1998. What's wrong with Bonferroni adjustments. British Medical Journal 316:1236-1238.

Peterson, A. T., A. G. Navarro-Sigüenza, AND H. Benítez-Díaz. 1998. The need for continued scientific collecting: A geographic analysis of Mexican bird specimens. Ibis 140:288-294.

Rappole, J. H. 1995. The Ecology of Migrant Birds: A Neotropical Perspective. Smithsonian Institution Press, Washington, D.C.

Rappole, J. H., and D. W. Warner. 1980. Ecological aspects of migrant bird behavior in Veracruz, Mexico. Pages 353-393 in Migrant Birds in the Neotropics: Ecology, Behavior, Distribution, and Conservation (A. Keast and E. S. Morton, Eds.). Smithsonian Institution Press, Washington, D.C.

Remsen, J. V., JR. 2001. True winter range of the Veery (Catharus fuscescens): Lessons for determining winter ranges of species that winter in the tropics. Auk 118:838-848.

Russell, K. B. 1981. Differential winter distribution by sex in birds. M.S. thesis, Clemson University, Clemson, South Carolina. 
Selander, R. K. 1966. Sexual dimorphism and differential niche utilization in birds. Condor 68:113-151.

Sherry, T. W., AND R. T. Holmes. 1997. American Redstart (Setophaga ruticilla). In The Birds of North America, no. 277 (A. Poole and F. Gill, Eds.). Academy of Natural Sciences, Philadelphia, and American Ornithologists' Union, Washington, D.C.

Sokal, R. R., and F. J. Rohlf. 1995. Biometry, 3rd ed. W. H. Freeman and Company, New York.

Vidal, R. M., C. Macías-Caballero, and C. D. Duncan. 1994. The occurrence and ecology of the Golden-cheeked Warbler in the highlands of northern Chiapas, Mexico. Condor 96:684-691.

\section{Appendix}

Scientific collections contributing specimen data to the Atlas of Mexican Bird Distributions project (Peterson et al. 1998; Navarro S. et al. 2002, 2003), and from which data were used in our analyses, include the following: Academy of Natural Sciences, Philadelphia; American Museum of Natural History, New York; Bell Museum of Natural History, Minneapolis; British Museum (Natural History), Tring; Canadian Museums of Nature, Ottawa; Carnegie Museum of Natural History, Pittsburgh; Delaware Museum of Natural History, Wilmington; Denver Museum of Natural History, Denver; The Field Museum, Chicago; Fort Hays State University, Hays (Kansas); Iowa State University, Ames; Louisiana State University Museum of Natural Science, Baton Rouge; Moore Laboratory of Zoology, Occidental College, Los Angeles; Museo de Zoología, Facultad de Ciencias, Universidad
Wallace, G. E., H. González Alonso, M. K. McNicholl, D. Rodríguez Batista, R. Oviedo Prieto, A. Llanes Sosa, B. Sánchez Oria, and E. A. H. Wallace. 1996. Winter surveys of forest-dwelling Neotropical migrant and resident birds in three regions of Cuba. Condor 98:745-768.

Wunderle, J. M., JR. 1992. Sexual habitat segregation in wintering Black-throated Blue Warblers in Puerto Rico. Pages 299-307 in Ecology and Conservation of Neotropical Migrant Landbirds (J. M. Hagan III and D. W. Johnston, Eds.). Smithsonian Institution Press, Washington, D.C.

Associate Editor: M. T. Murphy

Nacional Autónoma de México, México (D.F.); Museum of Comparative Zoology, Harvard University, Cambridge; Muséum Nationale d'Histoire Naturelle, Paris; Museum of Vertebrate Zoology, Berkeley; Natural History Museum of Los Angeles County, Los Angeles; Natuurhistorische Museum, Amsterdam; Peabody Museum, Yale University, New Haven; Royal Ontario Museum, Toronto; San Diego Natural History Museum, San Diego; Southwestern College, Winfield (Kansas); Texas Cooperative Wildlife Collection, College Station; Universidad Michoacana de San Nicolás de Hidalgo, Morelia; University of Arizona, Tucson; University of British Columbia Zoology Museums, Vancouver; University of California at Los Angeles; University of Kansas Natural History Museum, Lawrence; University of Nebraska, Lincoln; U.S. National Museum of Natural History, Washington, D.C.; and Western Foundation of Vertebrate Zoology, Camarillo (California). 